\title{
Pitanje početaka svijeta - filozofija znanosti i epistemološki oprez Tome Akvinskog
}

\author{
Marina Novina*, Anto Gavrić**
}

\begin{abstract}
Sažetak
U više svojih tekstova Tomo Vereš je naglašavao potrebu detaljnijeg istraživanja pojedinih Akvinčevih tekstova te je tako inspirirao i ovo istraživanje koje poseban naglasak stavlja na Tomine komentare Aristotelovih djela, posebice O nebu, raspravu O vječnosti svijeta te niz pitanja iz prvoga dijela u Summa theologiae $i$ drugoga dijela u Summa contra gentiles. Istaknuti tekstovi sama su srž stare rasprave o početcima koja uključuje pitanje o vječnosti svijeta i propitivanje pojma stvaranja, više istaknutih filozofijskih tema, poput pitanja vremena, ali $i$ epistemološko pitanje granica spoznaje, te odnosa filozofije, znanosti i teologije. Ta su pitanja danas iznimno aktualna, osobito u kontekstu suvremene kozmologije, iz koje je proizišla teorija velikog praska, razni modeli univerzuma, prijedlozi multiverzuma i sl. Cilj je ovoga istraživanja utvrditi koliko su istaknuti Akvinčevi tekstovi, uključujući razlikovanja pojmova teološkog stvaranja, metafizičkog $i$ prirodnog početka, važni u kontekstu suvremenih tematiziranja pitanja početa$k a$, imajući u vidu očuvanje znanstvenosti i relevantne teme filozofije znanosti $i$ dijaloga znanosti, filozofije i teologije.

Ključne riječi: Toma Akvinski, vječnost svijeta, creatio, metafizički početak, prirodni početak, veliki prasak, filozofija znanosti, epistemološki oprez
\end{abstract}

\section{Uvod}

U tekstu naslovljenom Toma Akvinski - preteča Nikole Kopernika? Tomo je Vereš prije četrdeset godina napisao: ${ }^{1}$ »Namjera nam je da iznesemo pred našu javnost ponešto detaljnije dva teksta Tome Akvinskog na čiju važnost, po našem

* Dr. sc. Marina Novina, asistent, Fakultet filozofije i religijskih znanosti Sveučilišta u Zagrebu. Adresa: Jordanovac 110, 10000 Zagreb, Hrvatska. E-pošta: marina.novina@ffrz.hr

** Izv. prof. dr. sc. Anto Gavrić, Fakultet filozofije i religijskih znanosti Sveučilišta u Zagrebu. Adresa: Jordanovac 110, 10000 Zagreb, Hrvatska. E-pošta: anto.gavric@ffrz.hr

1 Vereš je taj tekst 1973. objavio i u splitskom časopisu Crkva u svijetu, 7(3), 237-245, povodom 500. obljetnice Kopernikova rođenja (1473.) i uoči 700. obljetnice smrti Tome Akvinskoga (1274.), a 1978. preveden je i na francuski: Thomas d'Aquin précurseur de Copernic? Atti del Congresso Internationale, 9, 247-253. 
sudu, još nije dovoljno upozoreno, a iz kojih se vidi da je Toma relativizirao vrijednost svih astronomskih sustava. I to s načelnog spoznajnog stajališta, poput Galileja« (Vereš, 1978, 81).

Malo dalje, nakon što je izložio dva relevantna ulomka, Vereš je postavio četiri pitanja vezana uz iznesene Tomine tekstove. Prvo pitanje glasi: »Kako se moglo dogoditi da dosad [...] nije dovoljno jasno ukazano na njihovo značenje [iznesenih ulomaka] u povijesti astronomije? « (Vereš, 1978, 82). U odgovoru na to pitanje Vereš je istaknuo da je narav tog pitanja takva da se na njega najbolje može odgovoriti nagađanjem te da je za novovjekovne tomiste najvjerojatnije da se »nisu bavili proučavanjem Tomine prirodoznanstvene misli, osim njezinim filozofijskim osnovama, jer su se pomirili s posvuda raširenim globalnim uvjerenjem da je ta misao nadvladana napretkom modernih prirodnih znanosti« (Vereš, 1978, 84). No, nastavlja Vereš,

da ironija povijesti bude potpuna, upravo su neki povjesničari znanosti, kao Pierre Duhem i drugi, počeli ukazivati u djelima Tome na odlomke kasnijih znanstvenih dostignuća. Rezultate njihova istraživanja prihvatili su noviji izdavači Tominih djela [...] Ali, po našem sudu, još nije dovoljno jasno uočen i izrečen znanstveni značaj dvaju navedenih tekstova Tome za povijest astronomije (Vereš, 1978, 84).

Istaknutim istraživanjem, iznesenim mišljenjem i postavljenom hipotezom Vereš je inspirirao ovo istraživanje koje na koncu dopunja i proširuje Verešovu hipotezu. Naime, Tomini komentari Aristotelovih djela, posebice $O$ nebu, rasprava $O$ vječnosti svijeta te niz pitanja iz prvoga dijela u Summa theologiae (STh I, q. 32, a. 45-49) i drugoga dijela u Summa contra gentiles (Toma Akvinski, 1993; SCG lib. 2, cap. 31-38) u kojima se nalaze i ulomci na koje je upozoravao Vereš, sama su srž stare rasprave o početcima. To je rasprava koja uključuje pitanje o vječnosti svijeta i propitivanje pojma stvaranja, te više istaknutih filozofijskih tema, kao što su pitanja vremena, epistemološko pitanje granica spoznaje i pitanje odnosa filozofije, znanosti i teologije. Ta su i takva pitanja danas vrlo aktualna, posebice u kontekstu suvremene kozmologije, iz koje je proizišla teorija velikog praska, razni modeli univerzuma, prijedlozi multiverzuma i sl. No, pitanja o početcima nisu samo aktualna, nego su i vrlo važna za znanost, filozofiju i teologiju, a njihovo ispravno razumijevanje za dijalog između tih disciplina.

U tom smislu mišljenja smo da je više Akvinčevih ulomaka (neke od njih ćemo istaknuti u ovom istraživanju) iznimno važno, kako za povijest astronomije, odnosno kozmologije, tako, pa i više, za znanost općenito, a osobito za suvremenu znanost u smislu očuvanja znanstvenosti tzv. epistemološkim oprezom, kako ga naziva Dominique Lambert (Lambert, 2003, 155). Toma Akvinski se pokazao vrsnim filozofom znanosti koji je anticipirao brojne relevantne teme suvremene filozofije znanosti (primjerice pitanje modela), a ističući važnost i autonomiju znanosti, filozofije i teologije, otvorio je prostor dijalogu koji jedini može svladati izazove na putu ostvarenja znanstvenosti, primjerice "Bog praznina" ili raznih izama, danas osobito scijentizma. Pred tim izazovima nađe se svaka disciplina u trenutku kada se suoči s granicama vlastite spoznaje. No, upravo su poznavanje 
granica vlastite discipline i otvorenost dijalogu jedini valjan put do spoznaje istine, prema kojoj po Akvincu teži svaka istinska spoznaja.

\section{Pitanje početaka - o vječnosti svijeta}

Pitanje početaka jedno je od središnjih pitanja svih religija, filozofije, a danas i niza znanstvenih disciplina (psihologije, sociologije, biologije, kemije, fizike, kozmologije itd.). Naime, aktualnost toga pitanja »proizlazi iz činjenice koja je davno uočena: priroda je složen sustav. U odnosu na taj sustav uzdižu se tri temeljne zagonetke (tzv. pitanja ili faze emergencije). Prva, odakle uopće nešto (jer svako 'nešto' - biće u prirodi — već jest 'nešto' složeno)? Druga, odakle život i treća, odakle svijest? « (Novina i Stanković, 2018, 154).

Sva istaknuta pitanja vrlo su aktualna, ali zagonetnošću zasigurno prednjači prvo pitanje: Odakle uopće nešto? To je pitanje staro koliko i čovjek, a povijest religija, filozofije i znanosti ga postavlja u sljedećem obliku: Je li svijet stvoren ili vječan?

Već su prvi filozofi pokušali ponuditi odgovor na to pitanje pa je tako Parmenid govorio o bitku kao vječnom, jednom, nedjeljivom i nepromjenjivom (Diels, 1983a, 195; DK 28B7-8), Demokrit o nepromjenjivim atomima koji su temeljna sastavnica svega što postoji (Diels, 1983b, 96-97; DK 68A37), a Platon o vječnim, savršenim i nepromjenjivim idejama kojih je pojavni svijet samo sjena. No u povijesti je do izražaja možda najviše došla Aristotelova tvrdnja o vječnosti svijeta — svijet je jedan, vječan, nestvoren i nepropadljiv (Aristotel, 2009, 33, 39; De caelo, 277b 25-30, 279b 19). Raspravljajući o Platonovoj teoriji o nastanku svijeta iz Timeja, Aristotel je istaknuo kako je nemoguće tvrditi da je svijet postao, ali da je ipak vječan (Aristotel, 2009, 39; De caelo, 279b 18-20). Ta je tvrdnja bila neizmjerno važna jer je imala velike posljedice za filozofiju prirode i oblikovala kozmološku misao sve do 16. stoljeća. No, kada je Tycho Brahe (1572.) na nebeskom svodu opazio novu zvijezdu (supernovu), to je značilo da u svijetu zvijezda dolazi do promjena. A to je pak narušavalo stoljećima staru Aristotelovu hipotezu i bilo jasan znak napuštanja Aristotelove filozofije prirode (Kragh, 2007, 51).

Aristotelove je hipoteze na nešto drugačiji način već nekoliko stoljeća ranije propitivao upravo Akvinac. Zaključci do kojih je došao, kako je istaknuo Vereš, možda su ostali u sjeni, ali to ne umanjuje njihovu važnost za kozmologiju i, štoviše, za suvremenu filozofiju znanosti, posebice iz epistemološke perspektive. Naime, Aristotelove su tvrdnje, zajedno s detaljima Ptolemejeva kozmološkog modela, preko arapskih autora početkom 13. stoljeća stigle do prvih sveučilišnih centara kršćanskog Zapada. Bio je to susret naizgled različitih i kontradiktornih razumijevanja pitanja početka svijeta $-\mathrm{s}$ jedne je strane bila ideja o vječnosti svijeta, koju je izvorno zastupao još Aristotel, čija je filozofija prirode bila izrazito dominantna, a s druge se strane nalazila ideja stvaranja, koja je dolazila iz judeokršćanskoga konteksta. 


\section{Pitanje početaka - ex nihilo}

Prema judeokršćanskom vjerovanju svijet je stvoren, nije vječan, odnosno svijet ima ograničeno trajanje i unatrag i unaprijed. U tom smislu, odnosno s obzirom na to da je svijet stvorio Bog, teza o vječnosti svijeta u ateističkom nazoru preuzima funkciju poricanja Božjega postojanja. Najveća novost u razmišljanju o početcima svijeta sastojala se u tome da se više nije smatralo kako je svijet stvoren od nekog već postojećeg materijala (elementa uzetog iz [vječnog] kaosa, kao što je to riječ kod Platonova Demijurga), nego ex nihilo. Naime, sam nauk o stvaranju ex nihilo ne nalazimo na stranicama Svetoga pisma niti se pojavljuje među temama ranoga kršćanstva u drugoj polovici 2. stoljeća kao ontološka i teološka tvrdnja kojom se izražava kontingentnost stvaranja. No o pitanju stvaranja već su se tada vodile brojne rasprave, a velik im je obol dao Aurelije Augustin, koji je učinio i korak dalje tvrdeći da stvaranje pretpostavlja činjenicu da je Bog uzrokovao postojanje kozmosa i da prije stvaranja nije postojalo vrijeme:

Evo odgovaram onome koji pita: 'Što je radio Bog prije nego što je stvorio nebo i zemlju?' [...] Nego kažem da si ti, Bože naš, Stvoritelj svega stvorenja, pa ako se pod imenom neba i zemlje razumijeva sve stvorenje, smiono kažem: 'Prije nego je Bog stvorio nebo i zemlju, nije radio ništa. Ako je naime nešto radio, što je to bilo ako ne stvorenje?' (Augustin, 1983, 261-262, 263; Confessiones, lib. 11, cap. 12 i 14).

Svakako naučavanje o creatio ex nihilo bilo je široko prihvaćeno kao zdravorazumsko. Na koncu su ga i crkveni oci (Tertulijan, Hipolit i Origen) istaknuli kao temeljni nauk koji mora biti istinit. Tako je nauk o creatio ex nihilo prihvaćen na Lateranskom saboru 1215. godine. To je dalo dodatnu važnost i obol kozmološkim raspravama i pitanjima odnosa znanosti, filozofije i teologije u srednjem vijeku (Kragh, 2007, 33).

U tom smislu, pitanja stvaranja i vječnosti svijeta, odnosno pitanje nekog kozmosa koji ne bi bio u skladu s Aristotelovom fizikom bilo je jedno od važnijih pitanja srednjovjekovlja u kontekstu filozofije prirode. Ali bilo je malo onih koji su bili spremni i voljni propitivati standardnu kozmologiju svojega vremena. S druge strane, bilo je to goruće teološko pitanje u kojem su brojni "mrmljali"2 protiv Aristotelove ideje o vječnosti svijeta kao kontradiktorne kršćanskomu pojmu stvaranja — ne čudi da je svatko tko bi tvrdio suprotno bio izvrgnut raznovrsnim kritikama same tadašnje znanstvene zajednice.

Tomini komentari Aristotelovih djela, posebice $O$ nebu, rasprava $O$ vječnosti svijeta i niz pitanja iz prvoga dijela u Summa theologiae (STh I, q. 32, a. 45-49) otkrivaju da je, uz pothvat prevođenja i tumačenja Aristotelovih djela, što ga je poduzeo s Albertom Velikim, Akvinac bio spreman na filozofijsku analizu pitanja stvaranja i njegovo suočavanje s filozofijom prirode i metafizikom. Ali, uz

2 Rasprava $O$ vječnosti svijeta u nekim rukopisima nosi naslov "Protiv onih koji mrmljaju" (Contra murmurantes), što ukazuje na tzv. idejni rat, koji se vodio oko pitanja stvaranja i vječnosti svijeta u kojem su teolozi augustinovskog smjera, posebice sv. Bonaventura, ustali protiv averoista Pariškog sveučilišta te pokušali dokazati da je vremenski početak ne samo kršćanska dogma, nego i razumski dokaziva istina, a pojam "stvaranja svijeta oduvijek" protuslovan (Vereš, 1978, 93-94). 
to, iz istih je tekstova razvidno da je Toma bio dobro upoznat s kozmologijom svojega vremena i, štoviše, spreman za njezino kritičko propitivanje radi osiguravanja puta $\mathrm{k}$ istini. Taj put se može osigurati jedino otvorenošću (istini od koga god dolazila) i spremnošću na dijalog koji podrazumijeva poznavanje identiteta i granica vlastite discipline.

\section{Pitanje početaka —o stvaranju}

Kako je istaknuo Gilbert Keith Chesterton, ako bi se Akvincu trebalo dodati koje ime, bilo bi to Toma od Stvoritelja (Chesterton, 1939, 89). Joseph Ratzinger je na to rekao kako je Chesterton pogodio bitan vid Akvinčeva djela jer su Stvoritelj i stvaranje srž Akvinčeva teološkog mišljenja, koje je punom umskom refleksijom vjere u stvaranje do svojeg cilja dovelo i kršćansko promišljanje antičke baštine. Iako vrlo važno, pitanje je stvaranja u teološkom kontekstu dugo ostalo u sjeni, baš kao i Toma. No u novije vrijeme to se uvelike promijenilo i otvorilo nova pitanja i zadaće (Ratzinger, 2008, 91-93). Nova pitanja nisu otvorena samo u teološkom, nego i u znanstvenom i filozofijskom kontekstu. Pitanje stvaranja nalazi se u dijaloškom okviru pitanja o početcima u kojem se susreću filozofija, znanost i teologija. U tom okviru neki tvrde da je kod pitanja početaka svijeta riječ o teološkom, neki da je riječ o pitanju metafizičke naravi, a tendencija je nekih suvremenih znanstvenika da tvrde kako odgovor na to pitanje može doći isključivo iz znanstvenoga konteksta. Štoviše, religiju ni ne spominju, a za filozofiju tvrde da je ionako mrtva (Hawking i Mlodinow, 2010, 5). Stoga, možemo s Lambertom, fizičarom i filozofom znanosti, reći kako je početak, odnosno postanak svijeta tipični suvremeni problem odnosa između znanosti i teologije (Lambert, 2003, 143). No, riječ o graničnom pitanju filozofije, teologije i prirodnih znanosti, što je uočio već i Akvinac te je za valjan dijalog u takvom kontekstu poželjno nanovo zaviriti u Akvinčevu misao, koja razjašnjava brojne nejasnoće i stranputice suvremenih rasprava o početcima, osobito o početku svijeta.

Naime, Toma piše: »stvaranje, koje je emanacija svega bitka, je iz ne-bića koje je ništa «. ${ }^{3}$ No malo dalje Akvinac ističe kako o stvaranju možemo govoriti samo analogno, odnosno u smislu promjene. Toma ističe:

U stvaranju kojim se proizvodi svekoliko bivstvo stvari ne može se prihvatiti nešto kao isto što se sada razlikuje od onoga što je bilo prije, nego samo pojmovno (prema umu): kao kad se shvati da neka stvar prije nije sasvim postojala, a zatim postoji: [...] No budući da način govorenja slijedi način razumijevanja, kao što je rečeno, stvaranje se prikazuje na način promjene, te se stoga kaže kako stvoriti znači učiniti nešto ni iz čega. ${ }^{4}$

3 »Creatio, quae est emanatio totius esse, est ex non ente quod est nihil« (STh I, q. 45, a. 1). Citati koji se donose na hrvatskom jeziku, a u navedenim su izvorima na stranim jezicima, prijevod su autora članka.

4 »Sed in creatione, per quam producitur tota substantia rerum, non potest accipi aliquid idem aliter se habens nunc et prius, nisi secundum intellectum tantum; sicut si intelligatur aliqua res prius non fuisse totaliter, et postea esse [...] Sed quia modus significandi sequitur modum intelligendi, 
To, dakle, znači kako stvaranje ne bi trebalo shvatiti kao neku radnju ili čin jer je to samo način izražavanja koji je analogan ljudskoj produkciji nekog objekta. No kod stvaranja, prema Tomi, nije riječ o nekom strukturiranom procesu, nego o čistom odnosu, i to svakog bića prema svojem Prvom uzroku:

Stvaranje stavlja u stvorenje nešto samo u vidu odnosa, jer što se stvara, ne nastaje gibanjem ili promjenom. Naime, ono što nastaje gibanjem ili promjenom, nastaje iz nečega što već postoji, a to se događa u proizvodnji nekih pojedinačnih bića. No to se ne može dogoditi u proizvođenju svekolikog bitka od sveopćeg uzroka svih bića koji je Bog. Stoga Bog, stvarajući, proizvodi stvari bez promjene. Ako se pak odstrani gibanje i od djelovanja i od trpnje, ostaje samo odnos, kao što je rečeno. Stoga preostaje da stvaranje nije u stvorenju ništa drugo doli neki odnos prema Stvoritelju, kao počelu njegova bitka; isto kao i u trpnji, koja biva s gibanjem, odnos se veže uz počelo promjene. $^{5}$

No tako ujedno postaje razvidno kako stvaranje nije gibanje, a iz toga slijedi da ni gibanje nije stvaranje te da ništa od onoga što formalno pripada nekomu gibanju ne ulazi u stvaranje (STh I, q. 46, a. 3, ad 2; Bajsić, 1998, 75). Dakle, stvaranje uistinu nema ništa s uzrokovanjem promjene i upravo to čini ključ Tomine analize pitanja početaka. Akvinac tako ističe kako je potrebno napraviti razliku između promjene koja je sadržana u vremenu i stvaranja koje je atemporalno. Stvaranje ne uzrokuje promjenu u nečemu, nego je korijen koji uzrokuje postojanje, i kao takvo se, s točke gledišta tvorevinskih entiteta, uvijek zbiva (Heller, 2013, 251). To je pak razlog zašto je u raspravi $O$ vječnosti svijeta Akvinac istaknuo kako ne vidi (kao i brojni drugi filozofi i teolozi) proturječje između vječnog postojanja svijeta i stvaranja:

Razmotrimo sada postoji li pojmovno proturječje između ovih dviju postavki da je Bog nešto prouzrokovao, a da ipak to oduvijek postoji. Bez obzira na to je li ta tvrdnja istinita, nije krivovjerno reći da je Bog mogao učiniti da oduvijek postoji ono što je stvorio. No smatram da bi ta tvrdnja bila neistinita kad bi sadržavala pojmovno proturječje. Ali ako tu nema pojmovnog proturječja, onda ne samo da nije neistinita, nego je štoviše i moguća; i bila bi zabluda kad bi se drukčije govorilo. [...] Da tu nema nikakva proturječja, može se pokazati na sljedeći način. Kad bi, naime, to bilo proturječno, razlog bi bio ili u jednoj od dviju postavki ili u objema, to jest ili zbog toga što djelatni uzrok (causa agens) mora trajanjem prethoditi svome učinku ili zbog toga što postojanju mora trajanjem prethoditi nepostojanje. U tom se smislu kaže da je stvoreni svijet postao od Boga iz ništavila (ex nichilo) (Akvinski, 2005, 160; De aeternitate mundi). ${ }^{6}$

ut dictum est, creatio significatur per modum mutationis, et propter hoc dicitur quod creare est ex nihilo aliquid facere« (STh I, q. 45, a. 2, ad 2).

5 »Respondeo dicendum quod creatio ponit aliquid in creato secundum relationem tantum. Quia quod creatur, non fit per motum vel per mutationem. Quod enim fit per motum vel mutationem, fit ex aliquo praeexistenti, quod quidem contingit in productionibus particularibus aliquorum entium; non autem potest hoc contingere in productione totius esse a causa universali omnium entium, quae est Deus. Unde Deus, creando, producit res sine motu. Subtracto autem motu ab actione et passione, nihil remanet nisi relatio, ut dictum est. Unde relinquitur quod creatio in creatura non sit nisi relatio quaedam ad creatorem, ut ad principium sui esse; sicut in passione quae est cum motu, importatur relatio ad principium motus« (STh I, q. 45, a. 3). Usp. Bajsić, 1998, 75. Usp. STh I, q. 46. 
Akvinac je najprije dokazao da prvo nije nužno, a zatim da drugo nije proturječno, tj. da nešto stvoreno bude oduvijek. No, više od toga, Akvinac je uspio pokazati da postoji razlika između pitanja o početcima i pitanja o stvaranju.

\section{Pitanje početaka - veliki prasak}

Možda se više puta u povijesti činilo, ali zasigurno kada se u kontekstu razvitka suvremene kozmologije razvila ideja velikog praska, kako se rasprava o početcima može zatvoriti. Znanost je došla do odgovora. Taj je odgovor ideja velikog $\operatorname{praska}^{7} \mathrm{i}$ danas je nalazimo u kontekstu "standardnoga kozmološkog modela" koji predstavlja trenutačno najbolji (matematički) model (opis) univerzuma (Taylor, 2013, 33). Naime, standardni kozmološki model na temelju teorije velikog praska i empirijskih podataka, koji govore u prilog širenja univerzuma, ${ }^{8}$ pretpostavlja da su prostor, vrijeme, energija, sile i masa, odnosno sve što nam je danas poznato nastali, tj. proširili se, iz singularnosti iznimno visoke gustoće i temperature do svojeg trenutačnog relativno "hladnog" i razrijeđenog stanja, čije širenje još uvijek traje (Ryden, 2006, 6). U tom smislu teorija velikog praska, tj. standardni kozmološki model, događaj nastanka univerzuma smješta u vrijeme prije približno 13,7 milijardi godina. Preciznije, teorija i model opisuju razvoj kozmosa od $10^{-43}$ sekundi nakon velikog praska te općom teorijom relativnosti pokušava zahvatiti i velike skale. Temelj standardnoga kozmološkog modela je ekstrapolacija lokalne fizike, opća teorija relativnosti (koja ujedno pretpostavlja kozmološko načelo), i tzv. empirijske potvrde širenja univerzuma, postojanje kozmičkog mikrovalnog pozadinskog zračenja (u novije vrijeme gravitacijskih valova) i primordijalna nukleosinteza. Model, dakle, opisuje geometriju prostorvremena u univerzumu, tvarni sastav i dinamiku evolucije univerzuma, a uključuje i kvantnu i statističku fiziku (Baryshev i dr., 1994, 11; Peebles, 1993, 5-6).

No dogodilo se upravo obrnuto, teorija velikog praska, iako je temelj trenutačno najboljeg opisa univerzuma, nije zatvorila, nego je u znanstvenom, filozofijskom i teološkom kontekstu otvorila brojne rasprave. U znanstvenom kontekstu ideja velikog praska je otvorila raspravu o razvitku alternativnih modela, teorija i naprednijih istraživanja malih i velikih skala, ali i samu znanost upoznala s njezinim tzv. horizontima. U filozofijskom smislu teorija velikog praska otvara rasprave o granicama spoznaje, granicama znanosti i znanstvene metode, o znan-

7 Pojam velikoga praska osmislio je Hoyle izrugujući se pretpostavci o prvotnom atomu Georgesa Lemaîtrea, koji je taj prvotni raspad jednog quantuma usporedio s vatrometom. Dakle, kod velikog praska nije riječ o nekoj eksploziji u klasičnom smislu. Uz to valja imati na umu kako se u fizikalnom smislu pod velikim praskom podrazumijeva rano stanje univerzuma u trenutku 10-43 sekundi, a u matematičkom smislu da se taj pojam poistovjećuje s jednom singularnošću prostorvremena, tj. točkom u kojoj sve fizikalne veličine postaju beskrajne (Lambert, 2003, 145).

8 U vezi s uporabom termina univerzum valja imati na umu kako se namjesto klasičnog određenja univerzuma kao sveukupnosti svega što postoji (neko cjelovito jedno), u fizici, odnosno suvremenoj kozmologiji, pod pojmom univerzuma misli na sveukupnost opservaciji dostupnih entiteta kako je to još 1908. istaknuo Orest Chwolson. To se razlikovanje pak izravno odražava na određenje suvremene kozmologije (Liddle i Loveday, 2009, 314-315, 81-82; Kragh, 2007, 106). 
stvenosti, o naravi empirijskih znanosti i naravi same suvremene kozmologije te o naravi i izboru između modela. U teološkom smislu otvara se pitanje o odnosu znanstvene teorije i teoloških tumačenja stvaranja kojima se teorija velikog praska prilično naravno prilagođava (Lambert, 2003, 146). Cilj ovoga istraživanja nije otkriti je li ideja velikog praska kompatibilna s teološkim tumačenjima, odnosno sa stvaranjem, nego upozoriti na nejasnoće koje se pojavljuju pri susretu znanosti, filozofije i teologije u pitanju o početcima. Naime, mišljenja smo da se u kontekst spomenutih rasprava izvrsno smještaju Akvinčeva uočavanja, napomene i razlikovanja. Štoviše, za očuvanje autonomije znanosti, filozofije i teologije, ali i za očuvanje znanstvenosti općenito nužno je vratiti se Akvinčevim naznakama, odnosno njegovu tzv. epistemološkomu oprezu.

\section{Pitanje početaka - Akvinčev epistemološki oprez}

Akvinčevi tekstovi, osobito Summa theologiae (STh I, q. 12, 32, 45 i 46), ${ }^{9}$ pozivaju na epistemološki oprez u raspravama o početcima, odnosno da se »čuvamo 'neumjesne znatiželje' koja nas može dovesti u šepave apologetike ili filozofije nespojive s kršćanskom teologijom « (Lambert, 2003, 155). Prema Tomi nužno je razlikovati tri pojma: teološko stvaranje, pod kojim se podrazumijeva metafizički odnos koji podržava svijet u njegovu bitku; metafizički početak, kojim se izražava pojava svijeta u njegovoj povijesti i prirodni početak svijeta koji se veže uz početnu singularnost ili stanje iz kojega je poteklo prostor-vrijeme (Lambert, 2003, 152).

U kontekstu tog razlikovanja nužno je uočiti kako je pitanje stvaranja stvar vjere. Naime, Akvinac objašnjava:

Samo vjerom držimo da svijet nije postojao uvijek i to se ne može dokazati, kao što je i prije rečeno o otajstvu Trojstva [q. 32, a. 1]. A tomu je razlog što se novost svijeta ne može dokazati iz samoga svijeta ${ }^{10}$. Naime, počelo dokazivanja je ono što nešto jest. Svaka stvar, po naravi svoje vrste, apstrahira od ovdje i sada; zbog toga se kaže da su opći pojmovi svugdje i uvijek. Stoga se ne može dokazati da čovjek, ili nebo, ili kamen nisu postojali uvijek. Isto tako niti polazeći od djelatnog uzroka, koji radi voljom. Naime, volja se Božja ne može istražiti razumom, osim ono što je svakako nužno da Bog hoće; a takvo nije ono što Bog hoće u pogledu stvorenjâ, kao što je rečeno. Može se pak Božja volja čovjeku očitovati objavom, na koju se oslanja vjera. Stoga, to da je svijet počeo sadržaj je vjere, a ne pak dokazivanja ili znanja. To je korisno imati na pameti, da ne bi možda netko, osmjelivši se dokazivati što je predmet vjere, navodio razloge koji nisu nužni, a koji onima što ne vjeruju dali povod izrugivanja jer bi mislili kako mi vjerujemo u istine vjere zbog takvih razloga. ${ }^{11}$

9 Prijevodi prvih dvaju pitanja mogu se naći u: Akvinski, 2005, 323-339, 371-374. Usp. Toma Akvinski, 1993, 477-509; SCG lib. 2, cap. 31-38).

10 Akvinac je zaključio da bi, prema Aristotelu, u takvom zaključivanju na djelu bio paralogizam zvan "prijelaz u drugi rod stvari".

11 »Respondeo dicendum quod mundum non semper fuisse, sola fide tenetur, et demonstrative probari non potest, sicut et supra de mysterio Trinitatis dictum est. Et huius ratio est, quia novitas mundi non potest demonstrationem recipere ex parte ipsius mundi. Demonstrationis enim 
Stvaranje, dakle, nužno ne uključuje ni metafizički ni prirodni početak. Metafizički pak početak, u smislu održavanja u bitku, uključuje stvaranje, ali ne uključuje prirodni početak. Naime, moguće je zamisliti da se u bitku pojavljuje savršeno statički univerzum, bez početne singularnosti. To su u suvremenom kontekstu prijedlozi poput teorije uravnoteženog stanja (Steady State Theory) ${ }^{12}$ i ideje multiverzuma (us. Carr, 2007; Ellis i dr., 2004), ${ }^{13}$ primjerice model univerzuma Stephena Hawkinga u kojem nema početne singularnosti ni ruba. Iako je Hawking isticao da ako univerzum nema »singularnosti ni granica, te ako ga u potpunosti opisuje unificirana teorija, to povlači duboke posljedice za ulogu Boga kao stvoritelja (Hawking, 1989, 184), odnosno da je njegov model, model univerzuma koji je samo jedan od svih mogućih, ipak brojna pitanja ostaju otvorena, primjerice: Kako se odvija kontinuirano spontano stvaranje materije? Odakle ansambl univerzuma? Konačno, pitanje koje je u tom smislu postavio Leibniz: »Zašto postoji nešto, a ne ništa? «, bolje nego ijedno drugo sažima metafizičku težinu problema (Heller, 2013, 250) na koji odgovor može dati samo ispravno shvaćeno stvaranje, ponajprije kao teološko i metafizičko pitanje, ali nikako znanstveno. Naime, u svim istaknutim idejama valja uočiti da potreba za ontološkim odnosnom, tj. održavanjem u bitku ne nestaje — jednostavno rečeno, i vječnost je ovisna o Bogu. Isključivanjem ili uključivanjem ideje velikog praska u model univerzuma o stvaranju ne govori se ništa, niti se lišava potrebe za održavanjem u bitku — sve ovisi o Bogu kao uzroku svojeg postojanja. U tom smislu dio greške u razumijevanju stvaranja nalazimo u pokušaju da se stvaranje poveže s idejom vremenskog početka, no, kako je Akvinac istaknuo, stvaranje je teološki koncept, pitanje odnosa, a ne prirodni početak — stvaranje je atemporalan čin. Svijet nije stvoren u vremenu, nego s vremenom, kako je zaključio već Augustin (Augustin, 1983, 261-263; Confessiones, lib. 11, cap. 12 i 13), a preciznim razlikovanjem promjene koja se odvija u vremenu i stvaranja koje je atemporalno potvrdio Akvinac. Stoga je Ernan McMullin mogao dodati: »Vrijeme je stanje stvorenja, znak ovisnosti [...]. Čin stvaranja je jedan jedini, u kojem ono što je prošlost, sadašnjost ili budućnost iz perspektive stvorenja iz Stvoritelja proizlazi kao jedna jedina cjelina « (Heller, 2013, 252). Stvaranje, dakle, ne isključuje ovi-

principium est quod quid est. Unumquodque autem, secundum rationem suae speciei, abstrahit ab hic et nunc, propter quod dicitur quod universalia sunt ubique et semper. Unde demonstrari non potest quod homo, aut caelum, aut lapis non semper fuit. Similiter etiam neque ex parte causae agentis, quae agit per voluntatem. Voluntas enim Dei ratione investigari non potest, nisi circa ea quae absolute necesse est Deum velle, talia autem non sunt quae circa creaturas vult, ut dictum est. Potest autem voluntas divina homini manifestari per revelationem, cui fides innititur. Unde mundum incoepisse est credibile, non autem demonstrabile vel scibile. Et hoc utile est ut consideretur, ne forte aliquis, quod fidei est demonstrare praesumens, rationes non necessarias inducat, quae praebeant materiam irridendi infidelibus, existimantibus nos propter huiusmodi rationes credere quae fidei sunt (STh I, q. 46, a. 2). Usp. Vereš, 1978, 94-95.

12 Teoriju su 1948. predložili H. Bondi, T. Gold i F. Hoyle (Bondi, 1998).

13 Ovdje valja istaknuti i sljedeće: iako je pojam multiverzuma kontradiktoran pojmu univerzuma, koji se uobičajeno određuje kao sveukupnost svega što postoji, upotrebljava se za opis tzv. ansambla univerzuma. Riječ je o ideji koju nije moguće potkrijepiti empirijskim dokazima jer je riječ o područjima koja se nalaze izvan granica opservaciji dostupnoga (Liddle i Loveday, 2009, 207). 
snost stvorenja o Stvoritelju ni mogućnost da je Bog započeo postojanje univerzuma u nekoj početnoj singularnosti, ali to ne pretpostavlja. No, stvaranje jest odgovor na Leibnizovo pitanje.

Konačno, u današnje vrijeme možda je najvažnije istaknuti kako prirodni početak nužno ne uključuje ni stvaranje ni metafizički početak. Naime, u slučaju prirodnog početka riječ je o geometrijskoj ili fizikalnoj singularnosti. Pod pojmom se singularnosti pak misli na »lokaciju u prostor-vremenu u kojoj se lome fizikalni zakoni, uglavnom zbog toga što fizikalne veličine kao što je gustoća postaju beskonačne « (Liddle i Loveday, 2009, 271). Nema izravne veze, kako je to isticao Georges Lemaître, između velikog praska (singularnosti) i stvaranja u teološkom smislu, odnosno prirodni početak nije povezan s Božjim postavljanjem svijeta u bitku i njegovim održavanjem (teološko stvaranje) ni s metafizičkom pojavom svijeta u njegovoj povijesti. Prirodni početak predstavlja točku beskonačne krivulje u kojoj koordinate prostora i vremena gube svoj smisao (Lambert, 2003, 149-151). Singularnost posjeduje uistinu posebna svojstva na matematičkoj i fizikalnoj razini, ali ne i na metafizičkoj razini jer, kako je razložio Lambert, nema te zrake svjetlosti koja bi se mogla usmjeriti prema ništici i uvesti na područje metafizike (Lambert, 2003, 149). Oslanjajući se na Akvinčevo razlikovanje, Lambert nadalje ističe kako vidimo da nas razmišljanje, odnosno istraživanje o prirodnom početku

ne može samo po sebi dovesti do teoloških pojmova. No zato je razvidno da se nikakva fizikalna kozmologija ne može razviti bez implicitne metafizičke pretpostavke o postavljaju svijeta u bitak. Jednadžbe teorije opće relativnosti opisuju geometrijsku i fizikalnu strukturu prostor-vremena, ali nam uopće ne objašnjavaju zašto se prostorvrijeme održava u svom bitku (Lambert, 2003, 153).

Fizika svojim metodama jednostavno ne može doprijeti dalje od prirodnog početka, koji ujedno predstavlja početak razvojnog procesa. No, u tom je smislu Akvinac, u pitanju 32 bio jasan:

Neka se stvar može obrazložiti na dva načina. Prvo tako da se postavka dokazuje dovoljnim razlogom: na taj se način u prirodnoj znanosti iznosi dovoljan razlog kojim se dokazuje da se nebo svagda kreće ujednačenom brzinom. Drugi je način obrazlaganja takav da izneseni razlog ne dokazuje dovoljno postavku, nego pokazuje da se na njezinu temelju činjenice slažu: tako se u zvjezdoznanstvu (astrologia) uzima pojam ekscentra i epicikla zbog toga što se tom pretpostavkom mogu protumačiti pojave u kretanju nebeskih tijela. Ali taj razlog nema dovoljnu dokaznu moć, jer bi se iste pojave vjerojatno mogle protumačiti i nekom drugom postavkom (STh I, q. 32, a. 1, ad 2).

Baš je za taj odlomak Pierre Duhem, u svojem klasiku filozofije znanosti, istaknuo kako je Akvinac izvrsno uočio nemogućnost fizikalne metode da ponudi u potpunosti sigurno objašnjenje (Duhem, 1991, 41).

Za razumijevanje pitanja o početcima nužno je razlikovanje teološkog stvaranja, metafizičkog i prirodnog početka te dijalog znanosti, filozofije i teologije. To su s jedne strane naznake autonomije znanosti, filozofije i teologije, a s druge strane potvrda relevantnosti tih pristupa. Ako se pitanje početaka želi uistinu 
razumjeti, nužno je očuvanje autonomije svakog pristupa, ali i njihov otvoren dijalog. Akvinac je tako svojim razlikovanjima upozorio da treba biti epistemološki oprezan u vidu povezivanja teološkog stvaranja, prirodnog i metafizičkog početka, i to s ciljem očuvanja znanstvenosti i otvaranja puta do istinske spoznaje pitanja početaka.

\section{Pitanje početaka — o prazninama}

Raspravljajući o pitanju početaka, Akvinac nije upozorio samo na nužno razlikovanje pojmova, nego i na granice spoznaje, odnosno na činjenicu da se svaka disciplina mora suočiti sa svojim granicama, s tzv. prazninama (prostorom neznanja). Upravo se s tih granica, odnosno upravo te praznine, pojavljuje niz relevantnih pitanja filozofije i filozofije znanosti. Ovdje ne možemo ulaziti na sve razine tih rasprava, ali valja istaknuti Akvinčev doprinos i teme koje je Akvinac naznačio, čiju važnost za znanost i filozofiju znanosti, kako je to isticao i Vereš, treba dublje istražiti.

Naime, s prazninama se suočava i znanost i filozofija i teologija na više razina, a posebice u kontekstu rasprave o početcima. Akvinac je u tom smislu dobro uočio da nam za govor o početcima na koncu ostaje analogija - treba prepoznati i prihvatiti tu granicu. No on je upozorio i na pitanje modela u znanosti. U komentaru Aristotelova djela O nebu Akvinac se, u odnosu na tada poznate modele kozmosa, nije bojao reći: »Ipak pretpostavke koje su oni pronašli nisu nužno istinite; naime, premda se takvim pretpostavkama mogu protumačiti pojave, ipak ne treba reći da su te pretpostavke istinite, jer se pojave na zvjezdanom nebu vjerojatno mogu protumačiti i na neki drugi način koji ljudi još nisu dokučili.«14 Kozmološki modeli su, dakle, već za Akvinca bili samo relativan opis. Time je Akvinac izravno upozorio i na granice znanstvene metode i na narav kozmoloških modela. Modeli su temeljni instrument suvremene znanosti, a pitanje naravi modela jedno je od aktualnih pitanja filozofije znanosti. Iz Akvinčevih je tekstova vidljivo da je imao svoj stav i o tom pitanju. Iako nije napisao raspravu o naravi modela, razvidno je da su Akvinčeva zapažanja iznimno korisna i dobrodošla u suvremene rasprave o naravi i ulozi modela u znanosti.

No za suvremene rasprave filozofije znanosti koje uključuju promišljanja o interdisciplinarnosti i komplementarnosti, a pretpostavljaju otvoreni dijalog, Akvinac se pokazuje još bitniji. Naime, svakomu dijalogu trebalo bi prethoditi najmanje dvoje: precizno i ispravno poznavanje identiteta vlastite discipline te poznavanje granica vlastite discipline, odnosno priznavanje postojanja praznina. Naime, praznine su "prostor" podložan različitim i često jednako valjanim inter-

14 »Illorum tamen suppositiones quas adinvenerunt, non est necessarium esse veras: licet enim, talibus suppositionibus factis, apparentia salvarentur, non tamen oportet dicere has suppositiones esse veras; quia forte secundum aliquem alium modum, nondum ab hominibus comprehensum, apparentia circa stellas salvantur« (Toma Akvinski, 1886, 186-187; De caelo, lib. 2, cap. 12, lect. 17, n. 2). 
pretacijama, što je vidljivo u kontekstu rasprava o početcima. Praznine možemo naći između jezika i stvarnosti koju pokušavamo objasniti, osobito stvarnosti koja nas nadilazi ili iza granica znanstvene metode. Akvinac se u tom smislu oslonio na analogiju, dobro znajući da je riječ o analogiji, na temeljita istraživanja i dijalog otvoren prihvaćanju istine, od koga god ona dolazila. Akvinčeva je misao važna i danas, možda stoga što je znao ono što mnogi danas ne znaju. Akvinac je znao ostati znanstven - priznati postojanje praznine i nemogućnost pružanja utemeljenog odgovora, te u tom smislu razlikovati vjersko uvjerenje, razumski razlog i tzv. empirijski utemeljenu tvrdnju. Tako je već iz citiranih ulomaka i istaknutih tekstova razvidno kako se Toma Akvinski pokazao vrsnim filozofom znanosti.

U tom je smislu Toma izbjegao i dvije velike zamke, zamku tzv. "Boga praznina" i raznih "-izama", u današnje vrijeme osobito scijentizma. Naime, sintagma "Bog praznina" poznata je od Newtona, koji je koristeći vlastite zakone gibanja mogao s velikom točnošću izračunati putanje planeta, ali početni uvjeti planetarnih gibanja nisu bili određeni mehaničkim zakonima. Newton je smatrao da je te početne uvjete predodredio tzv. inteligentni dizajner. On je dao početni impuls mehanizmu kozmosa te s vremena na vrijeme intervenira kako bi uspostavio izgubljeni sklad. Kako je klasična mehanika napredovala, tako su se Božje intervencije pokazivale sve nepotrebnijima. Slični su se procesi odvijali i u drugim znanostima te se ispunjavanje praznina u našem znanju hipotezom Boga počelo izbjegavati. Naime, Boga ne bi trebali tražiti tamo gdje se naše znanje slama, nego tamo gdje je čvrsto (Heller, 2013, 249-250). Akvinac je upravo na tu zamku upozoravao u svojim tekstovima, osobito u raspravi $O$ vječnosti svijeta i u prvom dijelu Summa theologiae (I. q. 32 i q. 46). »Po njemu, dokazivanje nekih nedokazivih vjerskih datosti, kao što su Trojstvo i vremenski početak svijeta, ne samo da ne idu u prilog vjeri, nego joj mogu nanijeti i štete« (Vereš, 1978, 97). Prijelazi u tzv. "drugi rod stvari” štetni su i za teologiju i za filozofiju i za znanost. No Akvinac je kritikom kozmoloških modela, odnosno njihovim relativiziranjem, uputio na granice znanosti i činjenicu da se taj prijelaz u "drugi rod stvari” događa kada znanost ne prepozna granicu vlastite metode. ${ }^{15}$

Ujedno, iz naznačenih ulomaka proizlazi da je Akvinac htio »relativizirati u prvom redu apodiktičku vrijednost astronomskih sustava u odnosu na nepoznatu i nespoznatljivu cjelinu svemira « (Vereš, 1978, 87). Naime, Akvinac je upozorio na činjenicu da kozmos nije klasičan predmet istraživanja, nego po naravi jedinstven, te da se, s obzirom na to da se suvremena kozmologija temelji na ekstrapolaciji lokalne fizike, nužno suočava s granicom vlastite metode. Na to danas jedno od aktualnijih pitanja filozofije kozmologije Akvinac je odgovorio vrlo jasno, odnosno da se dokazivanje u kontekstu kozmologije temelji na nedovoljnim i nepotpunim razlozima te tako izbjegao zamku scijentizma. Isto je Akvinac

15 Bajsić je o tome pisao: »Materijalni svijet se, prema prirodnim znanostima, pokazuje kao skup vrlo suptilnih i ponekad paradoksnih struktura. Nije dakle čudo da razmišljajući o tim problemima uvodimo u sliku svijeta neopazice i po koji modus quo naših pojmova koji zapravo u tu sliku ne ulazi« (Bajsić, 1998, 78). Uočavanju i izbjegavanju takvih pogrešaka uči nas Akvinac. 
napomenuo i u kontekstu rasprave o vječnosti, odnosno vremenskom početku svijeta. Naime, kako čitamo u Summa theologiae, zaključivati na vremenski početak svijeta na temelju pojedinačnih primjera u njemu predstavlja bezrazložni paralogistički skok iz pojedinačnoga u sveopće (STh I, q. 46, a. 2) . A »tko ili što jamči da se cjelina ponaša kao dio, da obilježja jednog dijela zbiljnosti vrijede za svu poznatu i nepoznatu zbiljnost « (Vereš, 1978, 95). Akvinac smatra kako treba izbjeći takvu smiješnu misaonu naivnost (Vereš, 1978, 96). U tom je smislu i Arnold Benz istaknuo kako nama koji smo se naviknuli na znanstveni napredak možda teško pada ostaviti neodgovorenim pitanja o velikom prasku, no čini se da je dobro prihvatiti ono što je istaknuo poznati američki fizičar Richard Feynman: »Mogu živjeti sa sumnjom, nesigurnošću i neznanjem. Mislim da je puno zanimljivije živjeti s neznanjem, nego imati odgovore koji su možda pogrešni« (Benz, 2012, 55). Kako vidimo, davno prije Feynmana na to je upozorio Akvinac koji je tako kao vrstan filozof znanosti kritičkim propitivanjem i upoznavanjem granica znanosti očuvao znanstvenost i radi spoznaje istine pozvao znanost, filozofiju i teologiju na otvoreni dijalog.

\section{Zaključak}

Pitanje početaka jedno je od aktualnih i zagonetnijih pitanja suvremene znanosti, filozofije i teologije. Najzagonetnije među pitanjima početaka zasigurno je ono: odakle išta? Na to su pitanje u povijesti pokušavali odgovoriti teolozi, filozofi, a danas i znanstvenici. U raspravu o početcima, osobito o pitanju stvaranja, odnosno vječnosti svijeta uključio se i Akvinac. Preciznije, Akvinčevi komentari Aristotelovih djela, posebice $O$ nebu, rasprava $O$ vječnosti svijeta te niz pitanja iz prvoga dijela u Summa theologiae (I, q. 32, a. 45-49) i drugoga dijela u Summa contra gentiles (Toma Akvinski, 1993; SCG lib. 2, cap. 31-38) srž su te stare rasprave i uključuju propitivanja ideje o vječnosti svijeta i pojma stvaranja, više važnih filozofijskih tema, poput pitanja vremena, epistemološko pitanje granica spoznaje te odnosa filozofije, znanosti i teologije. To su i danas posebno aktualna pitanja, osobito u kontekstu suvremene kozmologije iz koje nam stiže teorija velikog praska, razni modeli univerzuma, prijedlozi multiverzuma i sl. Ispravno razumijevanje tih tema od posebne je važnosti za dijalog znanosti, filozofije i teologije, koji je u današnje vrijeme interdisciplinarnosti i komplementarnosti neupitan i nužan.

U ovom smo radu istaknuli više Akvinčevih ulomaka koji se pokazuju važni za povijest astronomije, odnosno kozmologije i, štoviše, za znanost općenito, a osobito za suvremenu znanost u smislu očuvanja znanstvenosti tzv. epistemološkim oprezom. Taj se epistemološki oprez otkriva u Akvinčevu razlikovanju promjene, koja se odvija u vremenu, i stvaranja, koje je atemporalan čin, odnosno u razlikovanju pojmova teološkog stvaranja, metafizičkog početka i prirodnog početka. Upućujući na Akvinčeva razlikovanja u kontekstu suvremenih kozmoloških ideja (modela), posebice velikog praska, postaje jasno kako 
nema sumnje da je nerazlikovanje između podrijetla stvorenja i problema njegova vremenskog početka posljedica misli koja nije dovoljno dorađena i istančana — bilo da se želi u singularnosti velikoga praska ukazati na nužnost upućivanja na stvaralački čin, bilo da se ovaj želi zanijekati na temelju njegove uklopljenosti u neki kvantni nekazualni kontekst (Morandini, 2012, 94).

Na kvalitetno istraživanje i izbjegavanje takve smiješne misaone naivnosti u svojim je tekstovima davno upozorio Toma Akvinski. Stoga smatramo kako se zbog kvalitete suvremenih rasprava nužno vratiti na Akvinčeve tekstove.

Toma Akvinski pokazao se vrsnim filozofom znanosti te je ujedno anticipirao brojne relevantne teme suvremene filozofije znanosti, primjerice pitanje modela. Navedenim je tekstovima istaknuo važnost i autonomiju znanosti, filozofije i teologije te tako, poznavanjem identiteta vlastite discipline i prihvaćanjem i poznavanjem njezinih granica, otvorio prostor dijalogu, koji je jedini kadar izbjeći zamke na putu ostvarenja znanstvenosti, kao što su primjerice "Bog praznina" ili raznih "-izama”, danas osobito scijentizma. Akvinac nam je tako ostavio valjani put spoznavanja istine.

Na kraju treba istaknuti kako cilj ovog istraživanja nije bio ispitivanje kompatibilnosti znanstvenih, filozofijskih ili teoloških ideja o pitanju početaka ili stvaranja, nego isticanje nejasnoća i teškoća s kojima se spomenute discipline suočavaju pri pokušaju odgovaranja na pitanja početaka, poglavito početka svijeta. Istančana misao sama vodi do odgovora na takva pitanja, Akvinac nas potiče upravo na takav pristup istraživanjima. Isto tako, cilj ovog rada nije bio otvarati rasprave filozofije znanosti u koje bi se mogla smjestiti Akvinčeva misao. Pokušali smo naznačiti teme zbog kojih bi važnost Akvinčeve misli trebalo detaljnije istražiti. Na takav je način ovo istraživanje svojim tekstom inspirirao Tomo Vereš. Možda nekomu ono postane inspiracijom da otkrije svjetlo istine na koje je upućivao i sam Toma Akvinski.

\section{Literatura:}

Aristotel (2009). O nebu. Beograd: Paideia.

Augustin (1983). Ispovijesti. Zagreb: Kršćanska sadašnjost.

Bajsić, Vjekoslav (1998). Granična pitanja religije i znanosti. Zagreb: Kršćanska sadašnjost. Baryshev, Yurij V.; Sylos Labini, Francesco; Montuori, Marco; Pietronero, Luciano (1994). Facts and ideas in modern cosmology. Vistas in Astronomy, 38(4), 419-500.

Benz, Arnold (2012). Darovani svemir: Astrofizika i stvaranje. Zagreb: Kršćanska sadašnjost.

Bondi, Hermann (1998). The Steady-State Theory of the Universe. U: John Leslie (ur.), Modern Cosmology \& Philosophy (str. 76-80). New York: Prometheus Books.

Carr, Bernard (ur.) (2007). Universe or Multiverse? Cambridge: Cambridge University Press.

Chesterton, Gilbert K. (1939). Otac zapadne kulture: Sv. Toma Akvinski. Zagreb: Naklada Istina.

Diels, Hermann (1983a). Predsokratovci: Fragmenti: I. Zagreb: Naprijed.

Diels, Hermann (1983b). Predsokratovci: Fragmenti: II. Zagreb: Naprijed.

Duhem, Pierre (1991). The Aim and Structure of Physical Theory. Princeton: Princeton University Press. 
Ellis, George F. R., Kirchner, U., Stoeger, William R. (2004). Multiverses and physical cosmology. Monthly Notices of the Royal Astronomical Society, 347(3), 921-936.

Hawking, Stephen W. (1989). A Brief History of Time. London: Bantam Press.

Hawking, Stephen W., Mlodinow, Leonard (2010). The Grand Design: New Answers to the Ultimate Questions of Life. New York: Bantam Press.

Heller, Michael (2013). Gdje se fizika susreće s metafizikom. U: Shahn Majid (ur.), $O$ prostoru i vremenu (str. 246-282). Zagreb: Misl.

Kragh, Helge (2007). Conceptions of Cosmos: From Myths to the Accelerating Universe: A History of Cosmology. Oxford: Oxford University Press.

Lambert, Dominique (2003). Znanosti i teologija: Oblici dijaloga. Zagreb: Kršćanska sadašnjost.

Liddle, Andrew; Loveday, Jon (ur.) (2009). Companion to Cosmology. New York: Oxford University Press.

Morandini, Simone (2012). Teologija i fizika. Zagreb: Kršćanska sadašnjost.

Novina, Marina; Stanković, Nikola (2018). Tvar — emergentni fenomen i poziv fizike na metafiziku. Obnovljeni život, 73(2), 153-167.

Peebles, Phillip J. E. (1993). Principles of Physical Cosmology. Princeton: University Press.

Ratzinger, Joseph (2008). U početku stvori Bog: Promišljanja o stvaranju i grijehu. Split: Verbum.

Ryden, Barbara (2006). Introduction to Cosmology. San Francisco: Addison-Wesley.

Taylor, Andrew (2013). Tamni Svemir. U: Shahn Majid (ur.), O prostoru i vremenu (str. 18-70). Zagreb: Misl.

Toma Akvinski (1886). Sancti Thomae Aquinatis Dostoris Angelici Opera omnia iussu impensaque Leonis XIII. P. M. edita: Tomus tertius: Commentaria in libros Aristotelis De Caelo et mundo de generatione et corruptione et meteorologicorum. Rim: Cura et studio Fratrum predicatorum.

Toma Akvinski (1988). Summa theologiae. Milano: Editiones Paulinae.

Toma Akvinski (1993). Suma protiv pogana: Svezak prvi. Zagreb: Kršćanska sadašnjost. [Za djelo Summa contra gentiles kod referiranja koristi se kratica SCG.]

Toma Akvinski (2005). Izabrano djelo. Priredio Anto Gavrić. Zagreb: Nakladni zavod Globus.

Vereš, Tomo (1978). Iskonski mislilac. Zagreb: Dominikanska naklada Istina. 
The Question of Origins of the World - The Philosophy of Science and Aquinas' Epistemological Caution

\author{
Marina Novina*, Anto Gavrić**
}

\title{
Summary
}

This research was inspired by Tomo Vereš through an article of his titled Thomas Aquinas - Forerunner of Nicolaus Copernicus? Aquinas' commentary on Aristotle's works, especially regarding On Heaven, On the Eternity of the World, and also a series of questions from the first part of the Summa Theologiae (I. q. 32, q. $45-q$. 49) containing the passages addressed by Veres. These are at the very core of the old discussion on origins which includes the question of the eternity of the world, the examination of the concept of creation and significant philosophical themes, such as the question of time, the limits of knowledge, and the relationship between philosophy, science and theology. Questions on origins are today extremely topical, especially in the context of modern cosmology from which the Big Bang theory comes as well as various models of the universe, multiverse proposals, etc. A correct understanding of these topics is extremely important for science, philosophy and theology and for the dialogue between them. In this regard, we have highlighted multiple fragments of Aquinas' which are crucial for contemporary science in terms of a scientific preservation of so-called epistemological caution. Aquinas' epistemological caution is manifested especially in his differentiation of the change that takes place in time and creation which is a temporal act, that is to say, in the differentiation of the concepts of theological creation, metaphysical origin and natural origin. Specifically, Aquinas' distinctions in the context of contemporary cosmological ideas (models), particularly of the Big Bang, indicate that unsophisticated thought leads us into traps, especially that of the so-called „God of Gaps" and of Scientism. These traps can be avoided through epistemological caution. Thus, Aquinas proved himself to be a great philosopher of science and at the same time anticipated many important topics in the contemporary philosophy of science, e.g. the question of models. He warned of the necessity for an autonomy of science, philosophy, and theology, and thus, by apprehending the identity of his own discipline and by accepting and recognizing its limits, he opened the space for dialogue, this being the only way to avoid traps on the path to the realization of scientificality. Thus, Aquinas has left us a valid way of apprehending truth and a multitude of topics to be more thoroughly explored in the light of his thought. Finally, since this research was inspired by an article by $T$. Vereš, perhaps some of these thoughts will inspire new research as well as a discovery of the light of truth to which Aquinas himself has pointed our attention.

Key words: Thomas Aquinas, eternity of the world, creation, metaphysical origin, natural origin, Big Bang, philosophy of science, epistemological caution

* Marina Novina, Ph.D., Teaching Assistant, Faculty of Philosophy and Religious Studies, University of Zagreb. Address: Jordanovac 110, 10000 Zagreb, Croatia. E-mail: marina.novina@ffrz.hr

** Anto Gavrić, Ph.D., Associate Professor, Faculty of Philosophy and Religious Studies, University of Zagreb. Address: Jordanovac 110, 10000 Zagreb, Croatia. E-mail: anto.gavric@ffrz.hr 